\title{
Dietary protein quality and malnutrition in Africa
}

\author{
Hettie Carina Schönfeldt* and Nicolette Gibson Hall \\ Department of Animal and Wildife Sciences, University of Pretoria, Pretoria, South Africa
}

(Submitted 3 August 2011 - Final revision received 21 February 2012 - Accepted 22 February 2012)

\begin{abstract}
The WHO (2007) Technical Report on protein and amino acid requirements in human nutrition states that the best estimate for a population average requirement is $105 \mathrm{mg}$ nitrogen $/ \mathrm{kg}$ body weight per day, or $0.66 \mathrm{~g}$ protein $/ \mathrm{kg}$ body weight per day. In many developing countries protein intake falls significantly short of these values. Apart from protein quantity, protein quality including bioavailability and digestibility, from different food sources, are currently on the global agenda. The 1st International Symposium on Dietary Protein for Human Health held in Auckland, in March 2011, and the consecutive Food and Agricultural Organization of the United Nations (FAO) Expert Consultation on Dietary Protein Quality, both highlighted the importance of assessing the quality of protein from different food sources through determination of amino acid content. Throughout the developed world, animal products and cereals are the two most important sources of protein; in developing countries this order is reversed. In low income countries only $3 \%$ of total dietary energy, as an indicator of diet composition, is derived from meat and offal, $11 \%$ from roots and tubers and $6 \%$ from pulses, nuts and oilseeds. The remainder of the dietary energy is mainly derived from cereal-based staple food. Although the production of livestock has increased in developing countries, the consumption of protein in these countries with people consuming the most limited amounts of protein are continually decreasing. Undernutrition, including insufficient consumption of protein, remains a persistent problem in the developing world, and although many diets within these developing countries are deficient in the quantity of protein compared to recommendations, the quality of the protein also strongly comes into focus.
\end{abstract}

Key words: Protein: Supply: Demand: Protein quality: Developing countries: Africa

\section{Highlights}

(1) Within developing countries, the amount of protein consumed is insufficient in comparison with requirements.

(2) The quality of protein from the foods consumed in developing countries is often limited and reduces the availability of the protein for use in the human body.

(3) The amount of livestock production in developing countries has marginally increased on average, yet persistent undernutrition, including low intake of goodquality protein, remains a major threat to livelihoods.

(4) New evidence indicates that well-fed populations probably need lower quantities of protein due to the high quality of protein consumed, compared to populations following a cereal based diet who need higher amounts of protein as they consume predominantly a lower quality protein diet.

(5) Increasing indigenous livestock production in Africa could increase the economic status of populations, increase availability and access to good quality protein sources, while simultaneously preserving the environment through promoting biodiversity.

\section{Introduction}

Protein is considered the dietary component that evokes the widest array of complex scientific, economic, environmental and political issues. It is viewed as the most expensive component of any diet, and is an essential ingredient forming part of a healthy balanced diet. Protein can be derived from both plant and animal sources, and meat and cereals are the two most important sources of protein in the world ${ }^{(1)}$.

Apart from different food sources containing different amounts of protein, the quality of the protein in the food source is also important. Animal-based food products in general contain the highest amount of protein per unit energy, and protein derived from animal foods is considered the best quality protein, providing all the dietary essential amino acids in adequate proportions. Within developing countries, dietary protein sources are mainly limited to cereals, and to a much lesser extent, to animal sources. Although animal products are regularly subject to scrutiny, from both health and environmental points of view, they occupy a critical position in the global food chain ${ }^{(2)}$. 
Irrespective of numerous national and international interventions, undernutrition remains a persistent problem in the developing world ${ }^{(3)}$. Although child mortality has decreased in Africa from 1990 to 2008, it remains the continent with the greatest mortality rate at more than double the global average. More than 140 African children out of 1000 have a probability of dying before the age of 5 years, with a health-life expectancy of 45 years $^{(4)}$. Furthermore, more than two thirds of low income countries' burden of disease is related to communicable diseases, maternal and perinatal conditions and nutritional deficiencies, in contrast to developed countries where non-communicable diseases, such as cardiovascular disease, diabetes and hypertension, often related to overnutrition, contribute to nearly $80 \%$ of the burden of disease ${ }^{(4)}$.

The significant effect that nutritional deficiencies and excesses have on the health status of populations has been well recognized and alleviation of these inbalances form part of most national health policies as both adequate food and good nutrition have been declared basic human rights $^{(5)}$. Already in 1933 Cicely Williams diagnosed kwashiorkor as a nutritional disease attributed to a lack of some amino acids and protein. Further awareness of the effects of malnutrition brought about by the events of World War II gave additional stimulus to research on protein deficiency and starvation. In the late $1950 \mathrm{~s}$ the official position of the WHO and FAO was that the single most important nutrient deficiency was protein. In 1959, Jelliffe created the term "proteinenergy malnutrition" recognizing that protein deficiency was not the only cause of malnutrition ${ }^{(6)}$. It is well-known that in Africa, iron-deficiency anaemia is widespread, iodine deficiency causes endemic goiter (which is a serious problem in some countries), and vitamin A deficiency is the leading cause of preventable blindness. In low income countries, only $3 \%$ of dietary energy is derived from animal products, $11 \%$ from roots and tubers, and $6 \%$ from pulses, while the remainder is made up mainly of cereals ${ }^{(7)}$. As part of the plight to combat malnutrition in Africa, evidence has shown that adding even small amounts of animal products to a plant-based diet can yield large improvements in maternal health and child development, along with many other positive health implications.

It seems simple to justify the need to increase animal production and consumption in Africa to increase the intake of good quality protein along with other essential nutrients. However, aspects such as food biodiversity, agricultural capacity, environmental sustainability, cultural traditions, and economic considerations along with both the negative and positive health effects of increased animal product consumption all need to be thoroughly examined before animal production can be promoted within national and international policy. This paper aims to review the nutritional implications of protein quantity and quality within developing countries, while taking these aspects into consideration.

\section{Protein requirements}

The WHO (2007) Technical Report on Protein and Amino Acid Requirements in Human Nutrition states that the best estimate for a population average requirement is $105 \mathrm{mg}$ nitrogen $/ \mathrm{kg}$ body weight per day, or $0.66 \mathrm{~g}$ protein $/ \mathrm{kg}$ body weight per day $^{(3)}$. The safe level was reported at $133 \mathrm{mg}$ nitrogen $/ \mathrm{kg}$ per day, or $0.83 \mathrm{~g}$ protein $/ \mathrm{kg}$ per day to meet the needs of a healthy adult population. In layman's terms, these recommendations mean that the average requirement for a $90 \mathrm{~kg}$ male will be around $75 \mathrm{~g}$ protein per day, which is approximately $10 \%$ higher than the recommendation from the $1985 \mathrm{FAO} /$ WHO/UNU report. These new values were based on the assumption that all protein sources have a protein digestibility corrected amino acid score (PDCAAS) of $1 \cdot 0$, and were calculated from reviewing studies done on nitrogen balance.

The 1985 report made recommendations for protein, based on studies conducted with high-quality protein sources only (animal-based protein sources), and did not incorporate some very important affecting factors, including the dietary sources of protein, age, gender, health status and energy expenditure of the individual. These have been addressed in the WHO 2007 report, resulting in the $10 \%$ increase in protein requirements. In addition to the global recommendations, in 2010, a study from the University of Copenhagen concluded that protein requirements should be based on criteria related to long-term health and well-being, rather than on nitrogen balance alone ${ }^{(8)}$. Positive roles of protein in promoting health at intakes beyond the recommendations have been scientifically documented. High intakes of leucine or nearly double the amounts of protein $(1.2 \mathrm{~g} / \mathrm{kg}$ body weight per day) than the recommendations, have been shown to promote muscle health and maintain long-term weight management ${ }^{(2)}$.

\section{Protein consumption}

Animal foods, as sources of protein, are likely to play a continued role in human $\operatorname{diets}^{(9)}$. The global consumption of total protein in 2005/7, based on disappearance values of food, was estimated to be $85 \mathrm{~g}$ protein per person, per day. This is more than the WHO recommendation of $75 \mathrm{~g}$ protein required by a $90 \mathrm{~kg}$ adult male per day. Within the developing world, this value drops to $80 \mathrm{~g}$ protein per person, per day, whereas Africa has a daily per capita value of $62 \mathrm{~g}$ per person per day $^{(9)}$. This amount has increased slightly since 1990/2 from $57 \mathrm{~g}$ protein, per person, per day. These values are presented in Table 1.

Although the intake values for Africa are already below the recommended amount for protein, the validity of the data, in terms of actual consumption is questionable and it is the opinion of the authors that these values based on disappearance (protein that disappears from the food supply rather

Table 1. Dietary protein consumption (g/person/day) ${ }^{(13)}$

\begin{tabular}{lcccc}
\hline & \multicolumn{4}{c}{ Year } \\
\cline { 2 - 5 } & $1990-92$ & $1995-97$ & $2000-02$ & $2005-07$ \\
\hline World & 76 & 80 & 82 & 85 \\
Developing countries & 69 & 74 & 76 & 80 \\
Africa & 57 & 58 & 59 & 62 \\
United States of America & 109 & 111 & 113 & 114 \\
\hline
\end{tabular}


than protein consumed) are overestimated. To capture such consumption data, the nutrient content of the food supply is calculated using data on the amount of food available for consumption and from the nutrient composition of foods obtained from reference tables. Estimates of per capita consumption for each food commodity are multiplied by the amount of nutrients in the edible portion of the food. Results for each nutrient from all foods are totalled and converted to amount per capita per day ${ }^{(10)}$. The disappearance values often overestimate consumption as it counts the food that exists in the marketplace and does not take into consideration what is lost throughout the system, at the retail outlet, the household, in private institutions and restaurants, and, cooking or plate losses. For the meat group (including beef, lamb, mutton, pork, poultry and fish), the situation is often more significant, as slaughter loss (skin, intestines, blood), bone loss, trimming loss, type of meat cut and cooking losses would significantly decrease the amount of product truly consumed, compared to the amount of raw product available $^{(11)}$. As an example, the FAO statistics indicate that a person consumed $109 \mathrm{~g}$ of protein per day in 1990-1992 in the United States of America based on disappearance values. The Third National Health and Nutrition Examination Survey $(1988-1991)^{(12)}$ calculated actual protein intake based on 24 hour dietary recalls, being between $80 \mathrm{~g}$ and $86 \mathrm{~g}$ per person per day. This indicates a difference of more than $20 \%$ in comparison. The reader is referred to Table 1 for dietary protein consumption trends over time.

According to FAO Statistics ${ }^{(13)}$, the five countries with the highest per capita consumption of protein based on disappearance values (United States of America, France, Greece, Israel and Iceland), had an increase in per capita consumption in the ten years, from 1994 to 2005. In contrast, the five countries with the lowest per capita consumption of protein (Congo, Liberia, Guinea-Bissau, Mozambique and Haiti) indicated a decrease in per capita consumption from 1994 to 2005. Considering the severity of these findings, it is important to highlight that in developing countries, protein intake would evoke different arguments than protein intake in developed countries, due to price, cultural beliefs, heritage availability and accessibility.

\section{Protein intake in comparison to recommendations}

It is recommended that a balanced diet contain a diversity of foods from all the different food groups, including starchy foods and cereals, vegetables and fruit, dairy products, meat and meat alternatives as well as fats and sugars. A snapshot of a typical western-style balanced diet, reported an intake of approximately $30 \mathrm{~g}$ protein in each of three meals consumed in one day. The three meals included breakfast (an egg, some bacon, a slice of bread, one fruit, a glass of milk and a slice of cheese), lunch (chicken burger and a fruitjuice), and dinner (spaghetti bolognaise). The total protein intake over the three meals was in-line with the recommendation for protein. The dietary diversity within this diet is also apparent, as foods from all the food groups are included. However, within developing countries, the situation looks significantly different. In marginalized communities, with financial constraints remaining one of the greatest causes of poor dietary status, food intake is inferior in both quantity and quality, with limited dietary diversity. As an example, in South Africa the population group with the lowest annual household income consumes a limited diet consisting mainly of refined white maize meal porridge, government subsidized brown bread and tea with milk and sugar. In one day, a person would on average consume $532 \mathrm{~g}$ maize meal porridge, $150 \mathrm{~g}$ brown bread, and $56 \mathrm{ml}$ milk and $22 \mathrm{~g}$ sugar with tea. ${ }^{(14)}$ Within this total daily intake, a marginal $30 \mathrm{~g}$ protein is consumed. It can be predicted that in many other marginalized communities daily protein intake reflects the amount of protein present in one balanced meal, predicting a significant shortfall in protein intake in these communities. Similar to the situation observed in rural South Africa, in many parts of Africa, rural diets are based predominantly on cereals, legumes and starchy roots and tubers. The consumption of animal foods such as meat, poultry and fish is limited, mainly because of economic, cultural and religious constraints. According to the Comprehensive African Agriculture Development Programme (CAADP) these trends reflect challenges not only related to reducing hunger, but also in the aim to ensure that people are consuming diets that are diversified and of good quality, providing all the necessary nutrients $^{(15)}$. As a result, the CAADP categorizes challenges for food security into three broad themes, namely those linked to food access, those linked to food utilization, and to those linked to dietary quality and diversification.

The nutritional impact of such a low intake of quality protein in developing communities leads to significant stunting and wasting (the visual consequences of protein deficiency). In South Africa, $16 \%$ of children are underweight for their age, and 1 in 5 children are stunted ${ }^{(16,17)}$. As a result, a significantly different approach to dietary guidelines and food policy is needed to be established in developing countries, compared to developed countries where protein consumption is often higher than recommended, animal foods are often consumed in abundance, and excess protein is utilized as an energy source.

\section{Protein quantity in foods}

To achieve the recommended daily protein intake, along with obtaining enough of the other essential nutrients, a diversity of foods is recommended in most national dietary guidelines and consumption tools. As mentioned previously, different food sources contain different amounts of protein, differentiating rather extensively between the different food groups. The major food groups contributing to protein intake are the meat and meat alternatives group (legumes), dairy, to a certain extent starchy foods and cereals, and to a lesser extent vegetables and fruit. In Table 2 the protein content in portions of selected foods are presented. It can be clearly seen that from a food group perspective a portion of meat, followed by legumes, contribute the most to protein intake per serving, while vegetables and fruit contribute the least. 
Table 2. Protein content in selected food servings from the different food groups ${ }^{(10)}$

\begin{tabular}{lclc}
\hline Food group & Serving size $(\mathrm{g})$ & Food & Protein $(\mathrm{g})$ \\
\hline Meat & 85 & Beef, lean cooked & 28 \\
& 85 & Chicken, cooked & 26 \\
Legumes & 150 & Fish, haddock, cooked & 36 \\
& 172 & Soya beans, cooked (1 cup) & 29 \\
Dairy & 196 & Split peas, cooked (1 cup) & 16 \\
& 256 & Red kidney beans, cooked (1 cup) & 13 \\
Starchy foods \& cereals & 245 & Full fat milk (1 cup) & 8 \\
& 28 & Cheddar cheese & 7 \\
Vegetable \& Fruit & 30 & Cottage cheese, low fat & 4 \\
& 185 & White rice, cooked (1 cup) & 15 \\
& 219 & Oat bran (1 cup) & 7 \\
& 25 & Bread, whole wheat (1 slice) & 3 \\
& 180 & Spinach, cooked (1 cup) & 5 \\
\end{tabular}

\section{Protein quality}

Animal based foods compared with other food types contain on average greater amounts of protein per portion consumed. When considering many cereals and vegetables, the palatability implications of consuming large portion sizes (which contain adequate amounts of protein), on a regular basis need to be considered. Also, other important factors apart from quantity of protein also need some consideration.

The procedures for measuring the protein quality of foods have been under review since they were first developed. In the proceedings of the 1978 World Conference on vegetable food proteins, Cowan (1979) ${ }^{(18)}$ doubted the of use of different animal models in determining protein digestibility. During the recent 1st International Symposium on Dietary Protein for Human Health numerous scientists reported on the conundrum surrounding determining protein digestibility and quality. PDCAAS is the method of choice for calculating utilizable protein based on amino acid content. The amino acids, methionine, lysine, tryptophan and threonine, most commonly limit the nutritive values of proteins in the human diet ${ }^{(19)}$. These amino acid concentrations are generally lower (in different proportions) in plant-based sources of protein. The correct combination of plant-based protein foods could increase the protein quality of the complete meal by compensating for the individual plant foods' amino-acid deficits, but this is often as difficult as including animal products, as overall food choice is limited.

According to Young and Pellet $(1994)^{(20)}$, the dietary indispensible amino acid, lysine, is found at a lower concentration in plant based foods, than in animal foods. However, this is not reflected consistently in Table 3 in which the lysine, methionine and cysteine contents, analyzed during various research studies, are summarized. It should be noted that values for sulphur containing amino acids (methionine and cysteine) are often underestimated due to analytical error, which complicates the interpretation of values obtained from different studies.

Apart from different plant products being limited in certain amino-acids, anti-nutrient factors in legumes, starches, cereals, vegetables and fruits also bind many nutrients, including protein, further inhibiting the complete absorption of the nutrient from the food into the human body after ingestion.
In developing communities, vegetable protein sources are often mixed with cereals for complementary feeding to increase protein quantity in meals. Both these foods contain high levels of phytic acid, which can inhibit trace element and mineral absorption, including the absorption of iron, zinc, calcium and manganese. As iron and zinc deficiencies are widespread in infants and young children in developing countries, the bioavailability of iron and zinc from complementary food is a major concern. Iron absorption may be as low as $2-3 \%$ from porridge based on whole-grain cereals and legumes ( $1 \mathrm{~g}$ phytic acid per $100 \mathrm{~g}$ product) even in iron-deficient subjects. With lower levels of phytic acids ( $\pm 1 \mathrm{mg}$ phytic acid per $100 \mathrm{~g}$ product), iron absorption would increase twofold ${ }^{(21)}$. To achieve degradation of phytic acid in plant based foods, complete enzymatic degradation of phytic acid is recommended, but not always possible. Animal based sources of protein do not contain anti-nutrient factors, and research has shown that the addition of even a small amount of animal products could significantly increase the absorption of the minerals iron and zinc.

\section{Animal products as good quality protein sources in Africa}

Animal-based proteins contain greater amounts of protein per portion, and contain all the essential amino acids, while not inhibiting the absorption of other essential nutrients. Although oversimplifying, increasing the consumption of animal food in developing countries would significantly increase the nutritional status of populations. However, many important factors complicate increased animal product intake within Africa.

\section{Demand for animal based foods in Africa}

There is a continued global demand for high-value animal protein. The global increase in per capita consumption of livestock is evident from the data given by Bruinsma (2003) ${ }^{(23)}$ who reported an increase from $24 \cdot 2 \mathrm{~kg}$ per year in 1964 to $36.4 \mathrm{~kg}$ per year in 1999 . The expected per capita consumption of animal produce according to Bruinsma (2003) and the Euro FIR Consortium should increase to $45.3 \mathrm{~kg}$ per year by $2030 .{ }^{(23)}$ However, in industrial countries, demand for live- 
Table 3. Lysine, methionine and cysteine content of selected food products as determined in different studies (adopted from FAO, 1981) (22) $^{(2)}$

\begin{tabular}{|c|c|c|c|c|}
\hline \multirow[b]{2}{*}{ Food source } & \multirow[b]{2}{*}{ Food } & \multicolumn{3}{|c|}{ Range $(\mathrm{mg} / 100 \mathrm{~g})$ from different studies } \\
\hline & & Lysine & Methionine & Cysteine \\
\hline \multirow[t]{8}{*}{ Animal products } & Beef and Veal (edible flesh) & $531-591$ & $147-182$ & $78-82$ \\
\hline & Chicken (edible flesh) & $384-606$ & $88-215$ & $64-114$ \\
\hline & Offal & $375-506$ & $138-181$ & $62-132$ \\
\hline & Mutton and lamb (edible flesh) & $438-589$ & $131-198$ & $63-144$ \\
\hline & Hen eggs & $375-467$ & $181-249$ & $113-189$ \\
\hline & Fish (fresh, all types) & $380-689$ & $120-290$ & $28-144$ \\
\hline & Cow milk (untreated) & $396-531$ & $147-171$ & $44-58$ \\
\hline & Cheese & $476-674$ & $140-210$ & $15-46$ \\
\hline \multirow[t]{4}{*}{ Legumes } & African locust bean & $325-444$ & $38-100$ & $50-113$ \\
\hline & Chick-pea & $406-463$ & $34-106$ & $50-94$ \\
\hline & Cowpea & $394-479$ & $50-119$ & $48-106$ \\
\hline & Soya bean & $313-477$ & $53-114$ & $51-114$ \\
\hline \multirow[t]{6}{*}{ Cereals and grain products } & Barley & $159-250$ & $63-250$ & $81-194$ \\
\hline & Maize & $100-214$ & $53-175$ & $38-200$ \\
\hline & Millet & $100-244$ & $84-246$ & $69-169$ \\
\hline & Rice (brown or husked) & $198-263$ & 117-194 & $30-79$ \\
\hline & Rye (whole meal) & $151-281$ & $59-181$ & $85-156$ \\
\hline & Wheat (whole grain) & $131-249$ & $63-156$ & $111-212$ \\
\hline \multirow[t]{2}{*}{ Roots and tubers } & Cassava & $208-354$ & $31-179$ & $25-154$ \\
\hline & Potato & $163-488$ & $54-125$ & $7-81$ \\
\hline \multirow[t]{5}{*}{ Vegetables } & Carrot & $200-252$ & - & $43-70$ \\
\hline & Cauliflower & $325-394$ & $50-163$ & - \\
\hline & Corn & $288-444$ & $94-175$ & $18-50$ \\
\hline & Pumpkin leaves & $394-400$ & $100-150$ & $50-69$ \\
\hline & Spinach leaves & $344-516$ & $119-138$ & $75-119$ \\
\hline
\end{tabular}

stock products is stagnant, or even in gradual decline ${ }^{(24)}$. Although meat is a food of choice in the diet of industrialised countries, the popularity of red meat in South Africa, in line with other countries, is consistently declining in favour of white meat and other non-meat proteins ${ }^{(25)}$. Although the price difference between white and red meat, and animal protein vs. plant protein, is recognized as contributing to this phenomenon, another important reason is the perceived health risk associated with the consumption of products considered to be high in total and saturated fat, along with environmental issues and animal welfare. Market saturation in developing countries, specifically due to price increases, is also currently being observed ${ }^{(24)}$, although FAO (2009) ${ }^{(26)}$ still report a marked increase in consumption in developing countries over time, compared to other food commodity groups.

Livestock products often contain a high fat content, especially saturated fat. In many studies, a consumption of meat and dairy products has been linked to the development of lifestyle-diseases including cancer, diabetes and cardiovascular diseases in both developed and developing countries. It should be noted that in most of these studies the type of meat, e.g. lean, high fat or processed, is not taken into consideration or reported upon. Further investigations have shown that the type of processing of meat and dairy products are linked to some of the causes, and further scientific research is needed to understand the exact link between the intake of animal products and these diseases. Thirdly, in developing countries where all nutrients, including energy, are often limited and most people are subject to harsh physical activity on a daily basis, high fat sources are not necessarily a poor food choice. This might be true for developed countries as well, as the French are one of the healthiest populations in the world, but they consume the world's highest per capita consumption of animal fat ${ }^{(27)}$. Yet, conventionally many policies and campaigns are recommending reducing the intake of animal products to limit the intake of saturated fatty acids. However, not all animal products are high in fat, and alternative initiatives such as consumer education campaigns, could be considered to encourage the intake of animal products with minimal fat, either by choosing the right products/cuts, cutting off excess/visible fat and minimize adding fat during cooking, preparation and portion size.

Furthermore, the increase in food prices experienced over the last decade has seen developing populations employ food coping strategies of which reduction in portion sizes, decreased dietary diversity, and ultimately the elimination of complete food groups has had a significant impact on nutritional status. As protein is viewed as one of the most expensive components in the diets, it is also the first component to be restricted or eliminated. Unfortunately, developing countries are the most affected by the food and financial crises ${ }^{(28)}$.

Apart from price and health messages affecting the demand for animal based protein foods, within Africa, livestock are considered culturally a sign of affluence and not necessarily as a source of food. In these communities, mainly cerealbased diets are consumed, supplemented with other plant foods, and livestock are sold in times of need. In severe cases, even products such as milk and eggs from their own livestock will be discarded due to cultural beliefs. Most Africans value cattle as an important traditional and economic asset. Lobola, a practice whereby a groom's economic status and gratitude is demonstrated by paying cattle to his 
future in-laws as compensation for losing their daughter, is still very popular.

Environmental concerns are also significantly influencing the development of current national guidelines and policy. Aspects such as greenhouse gas emissions, environmental sustainability and water and carbon footprint are under discussion. Although the majority of people in semi-arid Africa sustain themselves primarily by growing crops, this means of food production is not practised by all. Because of inadequate rainfall and high evaporation rates, average crop yields are low, and the risk of crop failure is high. Traditionally the inhabitants of these regions have relied on domestic grazing animals to supplement their food supply. Local livestock breeds have adapted to the harsh environment over many decades within the different conditions in Africa, and these livestock have a higher resistance to local pests and diseases, while forming part of the local agro-ecosystem. They also have a lower carbon and water footprint than many international breeds dominating global livestock production ${ }^{(29)}$.

\section{Availability of animal-based foods}

Mannathoko and Blajan (1989) ${ }^{(30)}$ reported that based on FAO statistics, the production of foodstuffs of animal origin had at the time not developed on the scale necessary to sustain a population which increased by over 14 million new consumers every year in Africa. Twenty years later, in 2009, FAO reported a rapid increase in livestock production in developing countries as a response to the increase in demand. However, this tempo was mainly observed in Asia, Latin America and the Caribbean, leaving Africa as a net importer of animal products ${ }^{(26)}$.

According to FAO (2009), the annual per capita consumption of animal products in Sub-Saharan Africa in 2005 was $13.3 \mathrm{~kg} / \mathrm{capita} /$ year in 2005 for meat, $30 \cdot 1 \mathrm{~kg} / \mathrm{capita} /$ year in 2005 for milk, and $1.6 \mathrm{~kg} / \mathrm{capita} /$ year for eggs. With a population of more than 770 million in 2005, production of more than $10 \cdot 2$ million tons of meat, $23 \cdot 2$ million tons of milk and 1.23 million tons of eggs would be needed to sustain this consumption. In 2005, production of meat was 9.3 million tons, 24.3 million tons of milk, and 1.5 million tons of eggs, indicating an opportunity for increased agricultural production of livestock, specifically for meat ${ }^{(26)}$.

The African Union Inter African Bureau for Animal Resources (AU-IBAR) of the Department of Rural Economy and Agriculture (DREA) is mandated to support and coordinate the utilization of livestock, fisheries and wildlife as resources for human well-being and economic development in the Member States of the African Union. AU-IBAR is also mandated under CAADP as the Lead Institution for mainstreaming livestock in the various national and regional CAADP compacts and Investment Plans. During their 8th conference in 2010, concerns were raised on the position of Africa as a net importer of animal products while opportunities for intra African trade are not fully exploited with an estimated outflow of more than US $\$ 4$ billion per year; the poor competitiveness of African producers in domestic, regional and global markets; the constraints for intra- and inter-regional trade in Africa caused by poor infrastructure, legislative barriers, persistence of non-tariff barriers including sanitary regulations, inadequate market intelligence and limited involvement of stakeholders along the value chain ${ }^{(31)}$. African countries have failed to successfully compete in domestic, regional and international markets due to a number of challenges including lack of infrastructure and support, difficulty in establishing businesses, lack of recognition of women in the economy, barriers to trade, lack agro-industrial capacities, lack of access to finance, limited laboratory facilities, inadequate product standards, limited market information systems and policy administration barriers ${ }^{(32)}$.

When focusing on the promotion of animal production in developing countries, it is often assumed that lack of food for the poor and hungry could be remedied by reducing the demand for animal feed. Each year livestock consume 77 million tons of protein from feed that is potentially suitable for human consumption, whereas only 58 million tons of protein is contained in food products supplied by livestock ${ }^{(33)}$. However, this oversimplification ignores various factors. Firstly, it should be kept in mind that proteins contained in animal products are consistently of higher quality for human nutrition than those in the feed provided to the animals. Secondly, hunger and food insecurity are, in most cases, not merely a supply problem but a demand problem, caused by lack of purchasing power ${ }^{(26)}$. Thirdly, livestock and their feed make a contribution to improving food security as they provide a buffer in the case of food shortages. During the previous food crises (1974/75 and 1981/82), global grain supplies fell and the livestock sector provided a buffer by switching to alternative feed sources which contributed to a lower demand for specific grains. A similar buffer function was seen in the recent food crises $(2007 / 8)^{(26)}$. As a fourth argument, it should be noted that livestock, and in particular indigenous small stock breeds, are often produced on marginal lands in countries where very little else can be produced and limited opportunities exist for cultivation of crops. Due to the often harsh climates and environments in Africa and the ecology of indigenous herd animals, most farmers in rural Africa are nomadic pastoralists who move on a daily basis and practice seasonal migration of herds. Unfortunately, as governments increase industrialization or cultivation of unoccupied land, the available grazing spaces for these nomads are decreasing at a rapid rate, and as a consequence the availability of animal products will inevitably decrease.

\section{Accessibility of animal-based foods}

As previously mentioned, hunger and food insecurity are not only related to the availability of food, but to the purchasing power of the individual, or the demand. Food access is defined as being when individuals have adequate incomes or other resources to obtain appropriate foods needed to maintain consumption of adequate nutrition level ${ }^{(34)}$. This accessibility to healthy foods is often a significant constraint in Africa. As an example, access to a supermarket or large grocery store is a problem for numerous rural households in developing countries, and often smaller spaza shops in the rural areas sell a smaller 
selection of foods at a higher price which are often unaffordable to the majority of the population.

Due to these constraints for African populations in both the availability and accessibility of animal products, these populations often consume a shelf-stable starch-based diet, supplemented by plant foods. To support consumption of animal-based foods, food assistance programmers need to be put in place (food transfers, food stamps, school feeding programmes, education etc.). Furthermore, price subsidies and controls, cash transfers, reduced consumption taxes and food-for-work schemes could all be implemented to increase access to better quality protein sources.

Nutrition-positive development projects help reduce inequalities in income distribution and are likely to improve the nutrition, health and quality of life of those currently deprived. Labour-intensive projects are often preferable to capital-intensive ones, and support for small farmers may be more useful from a nutritional perspective than assistance for large estates. Small farmers and especially women farmers are the most disadvantaged and require the most help. They are also the ones who receive the least assistance, in terms of both extension services and access to credit. In many countries, too little of the national budget is devoted to support for local agriculture, which is essential for social and economic development and for nutritional well-being ${ }^{(5)}$.

\section{Conclusions and recommendations}

Although the underlying causes of malnutrition extend well beyond the lack of access to certain types of food, (i.e. animal-based foods) the quality of the food source needs to be emphasized. Nutrient bioavailability and digestibility together with sustainability within an environmental approach all need to be included when policies to combat malnutrition are developed. Nutrient profiling of foods or ranking foods based on their nutrient composition has received ample interest globally, with a major focus on the interpretation thereof within the obesity epidemic and non-communicable diseases. Within developing countries, where malnutrition remains a significant health threat, a nutrient rich foods approach (aiming at quality, not just quantity), and facilitating dietary diversity could be valuable.

Policy development to promote local agricultural production of indigenous species at a small-farmer level would increase the availability and access to good quality protein sources (providing other essential nutrients as well), along with increasing the economic viability of the populations, and preserving the environment through the promotion of biodiversity.

\section{Acknowledgement}

There are no conflicts of interest. No sources of funding.

\section{References}

1. Grigg D (1995) The pattern of world protein consumption. Geoforum 26, 1-17.
2. Layman D (2010) The changing roles and understanding about dietary protein for life-long health. Foredraget blev holdt den 21.5. pa KU-life.

3. WHO (2007) Protein Amino Acid Requirements in Human Nutrition. Report of a Joint. WHO/FAO/UNU Expert Consultation. WHO Technical Report Series no. 935.

4. WHO (2010) World Health Statistics 2010. World Health Organization. WHO Library Cataloguing-in-Publication Data. ISBN 9789241563987.

5. Latham MC (1997) Human nutrition in the developing world. Food and Nutrition Series - No. 29, Food and Agriculture Organization of the United Nations, ISSN 1014-3181, Rome, 1997.

6. Allen LH (2002) Ending hidden hunger: the history of micronutrient deficiency control. Washington, DC, The World Bank. Background Paper for the World Bank/UNICEF Nutrition Assessment.

7. FAO (2008) FAOSTATS. Available online from www.fao.org.

8. Jakobsen LH (2010) Effect of protein intake on physiological functions. University of Copenhagen, Department of Human Nutrition. Thesis.

9. Millward DJ (1999) Meat or wheat for the next millennium? Proceedings of the Nutrition Society 58, 201-209.

10. United States Department of Agriculture National Nutrient Database for Standard Reference, Release 18 (2011).

11. Agriculture and Agri-Food Canada (2011) Available online www.agr.gc.ca.

12. Smit E, Nieto J, Crespo CJ, et al. (1999) Estimated of animal and plant protein intake in US adults: Results from the Third National Health and Nutrition Examination Survey, 1988-1991. Journal of the American Dietetic Association 99, 813-820.

13. FAOSTATS (2011) Food and Agriculture Organization of the United Nations International Statistics. Available online at http://faostat.fao.org.

14. Schönfeldt HC, Gibson N \& Vermeulen H (2010) The possible impact of inflation on nutritionally vulnerable households in a developing country using South Africa as a case study. Nutrition Bulletin 35, 253-266.

15. Comprehensive African Agriculture Development Programme (CAADP) (2009) Pillar 3 Framework for African Food Security (FAFS).

16. Zere A \& McIntye D (2003) Inequities in uder-five child malnutrition in South Africa. International Journal of Equility and Health 2, 7.

17. Abrahams Z, Mchiza Z \& Steyn NP (2011) Diet and mortality rates in Sub-Saharan Africa: Stages in the nutrition transition. BMC Public Health 11, 801-813.

18. Cowan JC (1979) Vegetable protein nutrition. Journal of American Oil Chemists' Society 56, 145.

19. Pieniazek D, Rakowska M, Szkilladziowa W, et al. (1975) Estimation of available methionine and cysteine in proteins of food products by in vivo and in vitro methods. British Journal of Nutrition 34, 175-190.

20. Young VR \& Pellet PL (1994) Plant proteins in relation to human protein and amino acid nutrition. American Journal of Clinical Nutrition 59S, 1203s-1212s.

21. Hurrell RF (2003) Influence of Vegetable Protein Sources on Trace Element and Mineral Bioavailability. Journal of Nutrition 133, 2973S-2977S.

22. FAO (1981) Amino-acid content of foods and biological data on proteins. Food and Nutrition Series No. 21. Food Policy and Food Science Service, Nutrition Division, FAO. ISBN 92-5-001102-4. Food and Agriculture Organization of the United Nations Rome, Italy. 
23. Bruinsma J. (2003) World Agriculture: Towards 2015/2030. An FAO Perspective, Available online http://www.fao.org/ DOCREP/005/Y4252E/y4252e00.htm.

24. Gerber P, Mooney HA \& Dijkman J, et al. (2010) Livestock in a changing landscape - Experiences and regional perspectives. Islandpress, Washington. ISBN: 9781 59726-673-4.

25. Scholtz SC, Vorster HH \& Matsego L (2001) Foods from animals can be eaten every day - not a conundrum!. South African Journal of Clinical Nutrition 14, S39-S47.

26. FAO (2009) The state of food and agriculture. Livestock in the Balance. Food and Agriculture Organization of the United Nations. Rome, 2009.

27. Gilland B (2002) World population and food supply - Can food production keep pace with population growth in the next half-century? Food Policy 27, 47-63.

28. Ortiz I, Chai J \& Cummins M (2011) Escalating food prices: The threat to the poor households and policies to safeguard a recovery for all. Unicef.
29. The Life Network (2011) Supporting biodiversity and livelihoods through Livestock Keepers' Rights. Available online at www.lifeinitiative.net.

30. Mannathoko M \& Blajan L (1989) International trade in animals and animal products: the African case. Rev. sci. tech. Off. int. Epiz 8, 625-646.

31. African Union Interafrican Bureau for Animal Resources (2011) Terms of Reference for Market Bahaviour Consultants.

32. New Partnerships for African Development (NEPAD) (2011) Concept note for the African Food And Nutrition Security Day. Investing in Intra-African Trade for Food and Nutrition Security. 30 October 2011, South Africa.

33. Steinfeld H, Mooney HA, Schneider F, et al. (2010) Livestock in a changing landscape. Drivers, Consequences and Responses. Island Press, Vol. 1.

34. UsSAID (1992) Policy determination: Definition of Food Security. April 13, 1992. PD-19. 